\title{
The impact of Distinctive Root Canal Instrumentation Systems on Endotoxin Lessening from the Root Canal: A Systematic Review and Meta-Analysis
}

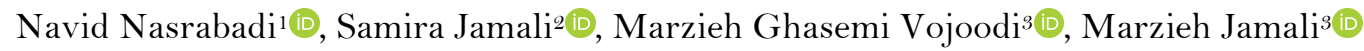

\begin{abstract}
1Department of Endodontics, School of Dentistry, Shahid Beheshti University of Medical Sciences, Tehran, Iran.
${ }^{2}$ Department of Endodontics, Stomatological Hospital, College of Stomatology, Xi'an Jiaotong University, Shaanxi, PR China.

${ }^{s}$ School of Dentistry, Kermanshah University of Medical Sciences, Kermanshah, Iran.
\end{abstract}

Correspondence: Samira Jamali, Department of Endodontics, Stomatological Hospital, College of Stomatology, Xi'an Jiaotong University, Shaanxi 710004, PR China. E-mail: samira.jamali90@yahoo.com

Academic Editor: Alessandro Leite Cavalcanti

Received: 23 February 2020 / Review: 20 May 2020 / Accepted: 26 June 2020 How to cite: Nasrabadi N, Jamali S, Vojoodi MG, Jamali M. The impact of distinctive root canal instrumentation systems
on endotoxin lessening from the root canal: a systematic review and meta-analysis. Pesqui Bras Odontopediatria Clín
Integr. 2021; 21 :e0029. https://doi.org/10.1590/pboci.2021.001

\begin{abstract}
Objective: To determine the impact of distinctive instrumentation systems of the root canals on the endotoxin lessening through the root canals. Material and Methods: From the electronic databases, MEDLINE, PubMed, Cochrane Library, Embase, ISI, Google Scholar have been used to perform a systematic literature review between 2015 and 2020. Therefore, a software program (Endnote X9) has been utilized for managing electronic titles. Searches were performed with keywords, "root canal," "instrumentation," "endotoxin," "root canal preparation," "biofilm” "endodontics," and "lipopolysaccharide." This systematic review has been conducted on the basis of the key consideration of the PRISMA StatementPreferred Reporting Items for the Systematic Review and Meta-analysis. Results: Hence, 163 potentially important abstracts and research topics have been discovered by electronic searches and three studies (3 RCTs) have been included. According to the outputs, any statistically significant differences have been not found between the rotary files and reciprocation (SMD 0.51, 95\% CI [0.11, 0.90], p=0.011) (I2 = 49.5\%; $\mathrm{p}=0.138$ ). Conclusion: Analyses indicated that instrumentation methods decreased the content of endotoxin from the root canals.
\end{abstract}

Keywords: Endodontics; Root Canal Preparation; Lipopolysaccharides. 


\section{Introduction}

Root canal therapy has been practiced since 1928, so that the success rate has tremendously increased [1]. In fact, combined instrumentations have been used to clean and shape the canals in the roots [2]. They have also been utilized for removing the infected soft (pulp) as well as hard (dentin) tissues for allowing the irrigating solution exchange across the whole length of the radicular spaces [3]. Moreover, they help the mechanical disruption of bio-films inside the root canal systems [4]. However, these factors' effect on the rate of failure or success of the root canal treatments remained ambiguous [5].

In fact, experts in the field presented a lot of instrumentations regarding the varieties in the crosssectional plan, kinematics, tapers and tip plan, and the sort of amalgam, aiming to facilitate the handle formation and lower laborious operations [6,7]. Studies reported that microbiota in the root canals is profoundly variable and the population-shift within the microbiome commonly occurs in the endodontic infection bio-films [8]. By definition, the root canal bio-films have been considered the complicated polymicrobial structures following the surface of the root canal shaped by the microorganisms, which invade the teeth' pulpal spaces and are related to the persistent root canal infections [9,10]. Moreover, the gram-negative anaerobic rods are the most common ones [11]. On the one hand, endotoxin has been regarded as one of the components (lipopolysaccharid - LPS) of the cell-walls of the gram-negative bacteria [12] that appeared for the stimulation of the bone resorption [13].

The Cone-beam Computed Tomography Analysis has determined the bone destruction and it has been found that pain has a relationship with the number of endotoxins in the root canals [14,15]. Therefore, endotoxin's lessening has been considered one of the vital measures to diminish the total bone destruction [14]. Furthermore, offering evidence-based outcomes would be imperative to assist in clinical practices' decision-making process [15]. Finally, the aim of this systematic review and meta-analysis has been to determine the impact of distinctive instrumentation systems of the root canals on the endotoxin lessening through the root canals.

\section{Material and Methods}

Search Strategy

From the electronic databases, PubMed, Cochrane Library, Embase, ISI have been used to perform a systematic literature between 2015 and 2020. Therefore, a software program (Endnote X9) has been utilized for managing electronic titles. Searches were performed with keywords, "root canal”, “instrumentation", "endotoxin", "root canal preparation”, “biofilm” “endodontics,” and “lipopolysaccharide” (Table1). This systematic review has been conducted on the basis of the key consideration of the PRISMA StatementPreferred Reporting Items for the Systematic Review and Meta-Analysis [16].

Table1. Search strategies of MeSH terms.

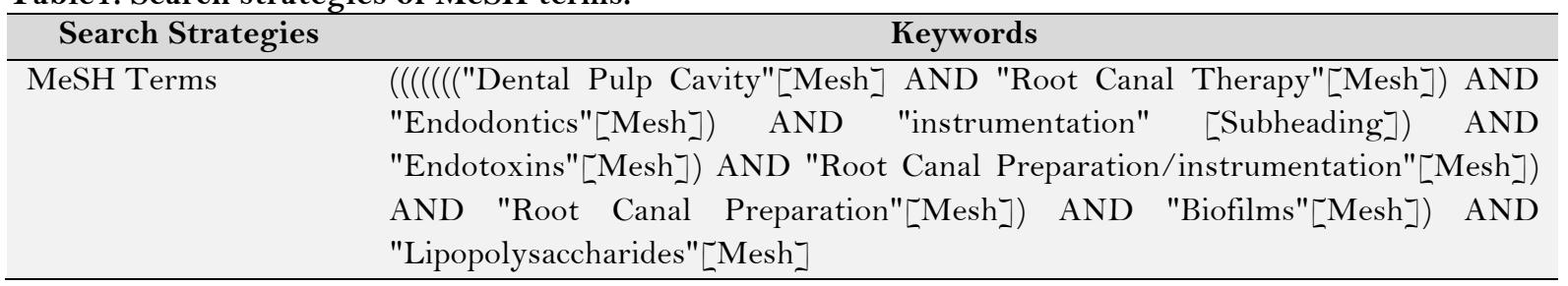

Selection Criteria 
The following inclusion criteria were established: 1) Randomized controlled trials studies, controlled clinical trials, and prospective and retrospective cohort studies; 2) In humans; 3 ) Full data; 4) Patient with root canal treatment; 5) Reciprocating and rotary instruments; 6) Baseline and post-intervention outcome; 7) Article that compared Reciprocating and Rotary instruments for microbial reduction; and 8) In English.

The following exclusion criteria were adopted: 1) In vitro studies, case studies, case reports and reviews; 2) Animal studies; and 3) Lack of the comparison of the instrumentation systems.

Data Extraction and Method of Analysis

The data have been extracted from the research included with regard to the study, years, study design, sample size, intervention, method, and outcome. The quality of the studies included was assessed using The Cochrane Collaboration tool [17). For Data extraction, three reviewers blind and independently extracted data from the abstract and full text of studies that included. Moreover, means of outcomes have been included in the meta-analysis. Then, the forest plots have been evaluated with the use of a software program (Comprehensive Meta-Analysis Stata V14, Biostat, Englewood, NJ, USA).

\section{Results}

A total of 163 potentially relevant titles and abstracts were found during the electronic and manual search. During the first stage of study selection, 71 publications were excluded based on title and abstract. For the second phase, the complete full-text articles of the remaining 89 publications were thoroughly evaluated. A total of 86 papers had to be excluded at this stage because they did not fulfill the inclusion criteria of the present review. Finally, a total of three publications fulfilled the inclusion criteria required for this systematic review (Figure 1).
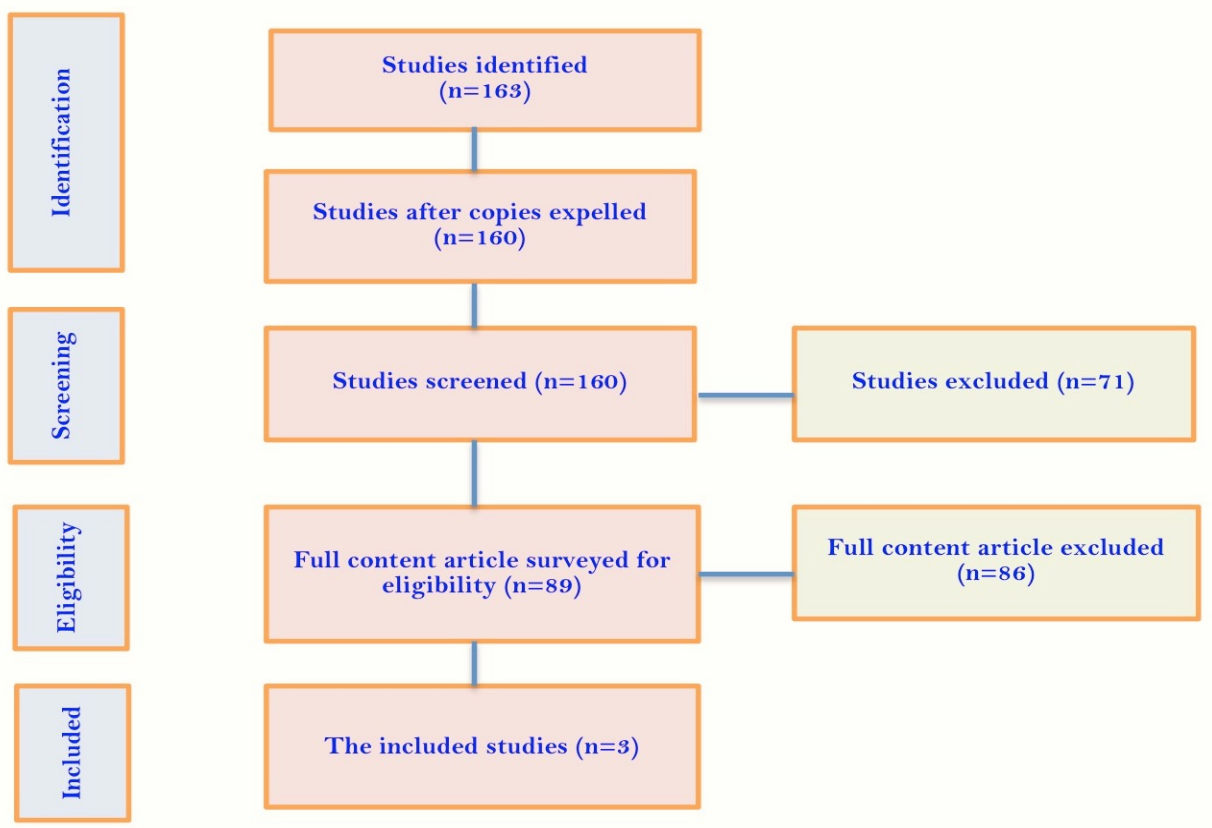

Figure 1. Study attrition diagram (PRISMA Statement).

Table 2 reports the individual studies in this meta-analysis. Therefore, three studies (3 RCTs) have been included (Table 2). The sample size of the study equaled 109 (Reciprocating $=60$, Rotary $=49)$. Notably, 
one study [18] investigated two Reciprocating instruments versus one Rotary instrument and the other two studies [19,20] examined one Rotary instrument versus one Reciprocating instrument.

Table 2. Studies selected for systematic review and meta-analysis.

\begin{tabular}{|c|c|c|c|c|c|c|c|c|}
\hline \multirow[t]{2}{*}{ Study } & \multirow[t]{2}{*}{ Design } & \multirow{2}{*}{\multicolumn{2}{|c|}{ Sample Size }} & \multirow[t]{2}{*}{ Intervention } & \multirow[t]{2}{*}{ Method } & \multicolumn{2}{|c|}{$\begin{array}{c}\text { Decreased } \\
\text { Endotoxin Content }^{1}\end{array}$} & \multirow[t]{2}{*}{ Outcome } \\
\hline & & & & & & REC & ROT & \\
\hline $\begin{array}{l}\text { Martinho } \\
\text { et al. [18] }\end{array}$ & RCT & 30 & $\begin{array}{l}\text { Wave One: } 10 \\
\text { Reciproc } \\
\text { instrument: } 10 \\
\text { Retreatment } \\
\text { system: } 10\end{array}$ & $\begin{array}{c}\text { Two } \\
\text { Reciprocating } \\
\text { instruments vs. } \\
\text { one Rotary } \\
\text { instrument }\end{array}$ & CLALA & $94 \%$ & $94.98 \%$ & $\begin{array}{c}\text { No significant } \\
\text { difference } \\
\text { between } \\
\text { instruments }\end{array}$ \\
\hline $\begin{array}{l}\text { Neves et al. } \\
{[19]}\end{array}$ & $\mathrm{RCT}$ & 59 & $\begin{array}{l}\text { Reciproc }=29 \\
\text { BioRace }=30\end{array}$ & $\begin{array}{c}\text { Reciproc + } \\
\text { BioRace }\end{array}$ & CLALA & $55 \%$ & $50 \%$ & $\begin{array}{c}\text { No significant } \\
\text { difference } \\
\text { between } \\
\text { instruments }\end{array}$ \\
\hline $\begin{array}{l}\text { Cavalli et } \\
\text { al. [20] }\end{array}$ & $\mathrm{RCT}$ & 20 & $\begin{array}{l}\text { Mtwo = } 10 \\
\text { Reciproc }=10\end{array}$ & $\begin{array}{c}\text { One Rotary } \\
\text { instruments vs. } \\
\text { one Reciprocating } \\
\text { instrument }\end{array}$ & CLALA & $95.05 \%$ & 91.85 & $\begin{array}{l}\text { No significant } \\
\text { difference } \\
\text { between } \\
\text { instruments }\end{array}$ \\
\hline
\end{tabular}

All studies exhibited a considerable decline in endotoxin content following treatments with the rotary and reciprocating instruments. In any case, there has been not any significant difference between the instrumentation groups for reducing endotoxin in each study. Therefore, the three papers have been included in our meta-analysis and then range and median have been used to estimate the standard deviation (SD) as well as the mean. According to the analyses, any statistically significant differences have been not observed between the rotary and reciprocation files (SMD 0.51, 95\% CI [0.11, 0.90], p=0.011) (I2 = 49.5\%; p=0.138) (Figure 2). Moreover, all papers' power analysis indicated fewer documents and a low quality randomized clinical trial with low control (Table 3).

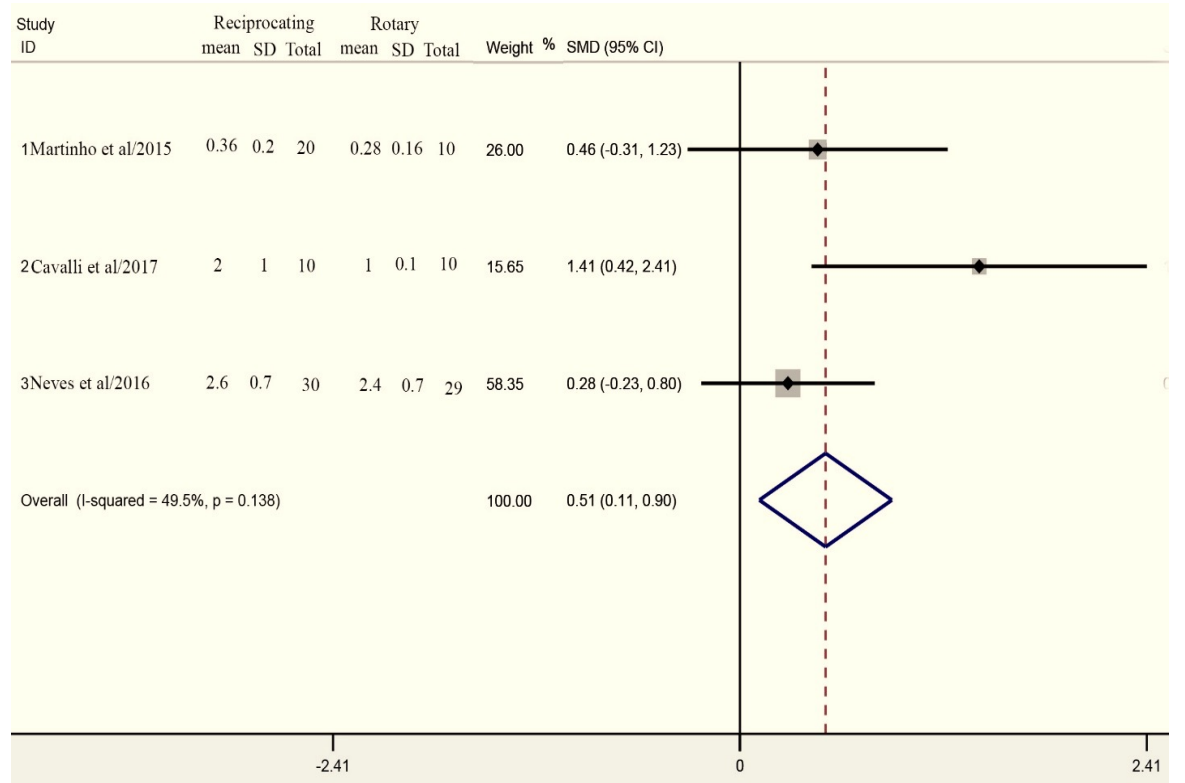

Heterogeneity chi-squared $=3.96($ d.f. $=2), \mathrm{p}=0.138$; I-squared (variation in SMD could be attributed to heterogeneity) $=49.5 \%$;MD test $=0: \mathrm{z}=2.53, \mathrm{p}=0.011$.

Figure 2. Forest plots showed effectiveness of rotary and reciprocating systems on microbial reduction. 
Table 3. Risk of bias.

\begin{tabular}{lcccccc}
\hline \multicolumn{1}{c}{ Study } & Randomization & $\begin{array}{c}\text { Allocation } \\
\text { Concealment }\end{array}$ & Blinding & $\begin{array}{c}\text { Blinding of } \\
\text { Outcome } \\
\text { Assessment }\end{array}$ & $\begin{array}{c}\text { Incomplete } \\
\text { Outcome } \\
\text { Data }\end{array}$ & $\begin{array}{c}\text { Selective } \\
\text { Reporting }\end{array}$ \\
\hline Martinho et al. [18] & Low & Unclear & High & High & Low & Low \\
Neves et al. [19] & Low & Unclear & Low & High & Low & Low \\
Cavalli et al. [20] & Low & Unclear & High & High & Low & Low \\
\hline
\end{tabular}

\section{Discussion}

The present systematic review and meta-analysis surveyed the impact of distinctive instrumentation systems of the root canals on the endotoxin lessening from the root canals. Analyses assessed the adequacy of the mentioned instrumentations on various parameters of the root canal treatments. However, the precise contribution of the kind of instrumentation on the clinical results is still ambiguous [21,22].

Only three articles satisfied our inclusion criteria for doing a systematic review; therefore, the rotary and reciprocating mechanisms have been compared in the two essential root canal treatments and retreatment. It is notable that all three studies utilized chromogenic kinetic LAL assay. In addition, the microbiological consideration showed high sensitivity at each arranges of assessment. Moreover, the baseline values and sterility check have been considered the crucial factors utilized to improve the research plan's accuracy and approve the outcome validity [23].

However, one of the critical parameters, which should be attended, would be the volume of irrigant utilized in the selected articles. As these articles compared the multifile rotary systems and the single file reciprocating systems and a multi-file hybrid system, we could conceive that the irrigant volume may be variable amongst the intervention groups because of the utilization time of the mentioned instrumentations has been different [24].

Results demonstrated that the single-file reciprocating system and the full-sequence rotary system had a comparative impact on the microbial reduction [21,25,26]. In this regard, Marinho et al. [18] revealed that Mtwo, Reciproc, Race, and ProTaper instruments created a largely considerable decline in the bacterial loads; however, there has not been any significant difference in the content of endotoxin. In any case, limited information has been published about the impact of the pure reciprocating movement on bacterial reduction.

Moreover, Reciproc and BioRaCe showed significant bacterial reductions though some bacteria have been identified by qPCR in $55 \%$ and $50 \%$ of the canals. Few investigations utilized various instrumentation methods as well as $\mathrm{NaOCl}$ irrigation [27,28]. This bacterial count may still be sufficient to maintain the infection. In addition, bacteria may stay in the root canal system due to the canal morphology such as lateral canals, apical ramifications, and isthmi, which could not be reachable by the instrument and irrigant [29].

Mechanical instrumentation could disturb the bacterial biofilm and had the potential to reduce the presence of bacteria within the primary root canal [30]. Furthermore, the rotary systems, ProTaper Universal, and Mtwo provided satisfactory geometry [31] and significant bacterial reduction in the root canal [32]. For example, Siddique et al. [33] systematic review evaluated the antibacterial efficacy of the rotary and reciprocating system in microbial reduction. It has been found that OES did not provide concrete evidence to show the increased antibacterial efficacy of the reciprocating system as compared to the rotary system. Moreover, clinical trials would be required to evaluate various instrumentation systems' efficacy in reducing bacteria from the root canal system. In addition, Neelakantan et al. [15] systematic review and meta-analysis evaluated the effects of diverse root canal instrumentations on decreasing the content of endotoxin from the 
root canal systems. They found that the instrumentation methods compared in the present review decreased endotoxin content from the root canals; however, there have been no significant differences between them. Finally, these two studies' results are consistent with the present review, with only the difference being in the systematic review and meta-analysis.

\section{Conclusion}

According to the analyses, the meta-analysis did not exhibit any statistically significant differences between the reciprocating and the rotary files. Therefore, instrumentation methods decreased the content of endotoxin from the root canal. Since just three studies (RCT) from 2015 to 2020 have been found on the topic of the study, it is necessary to have several researches for making a comparison between the current instrumentations.

\section{Authors' Contributions}

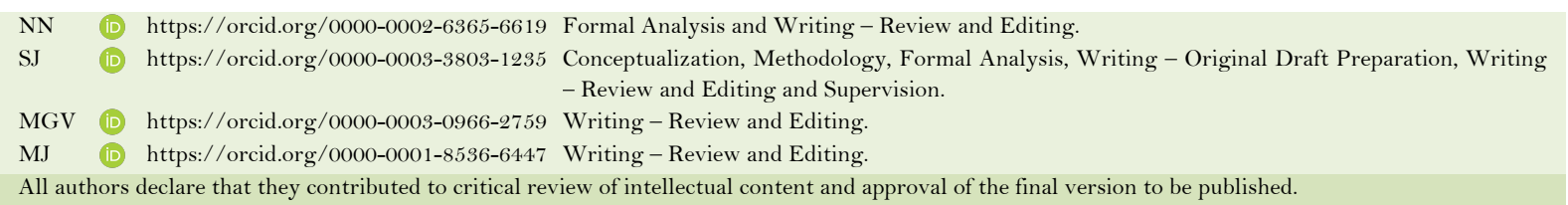

\section{Financial Support}

None.

\section{Conflict of Interest}

The authors declare no conflicts of interest.

\section{Data Availability}

The data used to support the findings of this study can be made available upon request to the corresponding author.

\section{References}

[1] Narayanan LL, Vaishnavi C. Endodontic microbiology. J Conserv Dent 2010; 13(4):233-9. https://doi.org/10.4103/0972-0707.73386

[2] Rivera-Peña ME, Duarte MAH, Alcalde MP, Furlan RD, Só MVR, Vivan RR. Ultrasonic tips as an auxiliary method for the instrumentation of oval-shaped root canals. Braz Oral Res 2019; 33:e011.

https://doi.org/10.1590/1807-3107bor-2019.vol33.0011

[3] Cumbo E, Melilli D, Gallina G. Irrigants in endodontics: a review. Int J Clinical Dent 2019; 12(1):37-62.

[4] Ioannidis K, Niazi S, Mylonas P, Mannocci F, Deb S. The synthesis of nano silver-graphene oxide system and its efficacy against endodontic biofilms using a novel tooth model. Dent Mater 2019; 35(11):1614-29. https://doi.org/10.1016/j.dental.2019.08.105

[5] Parashos P. Prognosis of Root Canal Treatment with Retained Instrument Fragment (s). In: Lambrianidis T. (eds) Management of Fractured Endodontic Instruments. Springer, Cham. https://doi.org/10.1007/978-3-319-60651-4__8

[6] Ahn S-Y, Kim H-C, Kim E. Kinematic effects of nickel-titanium instruments with reciprocating or continuous rotation motion: a systematic review of in vitro studies. J Endod 2016; 42(7):1009-17. https://doi.org/10.1016/j.joen.2016.04.002

[7] Plotino G, Ahmed HMA, Grande NM, Cohen S, Bukiet F. Current assessment of reciprocation in endodontic preparation: a comprehensive review - part II: properties and effectiveness. J Endod 2015; 41(12):1939-50. https://doi.org/10.1016/j.joen.2015.08.018

[8] Neelakantan P, Romero M, Vera J, Daood U, Khan AU, Yan A, et al. Biofilms in endodontics - current status and future directions. Int J Mol Sci 2017; 18(8):1748. https://doi.org/10.3390/ijms18081748

[9] de Paz LEC, Sedgley CM, Kishen A. The Root Canal Biofilm: London: Springer; 2015. 366p.

[10] Jhajharia K, Parolia A, Shetty KV, Mehta LK. Biofilm in endodontics: a review. J Int Soc Prevent Communit Dent 2015; 5(1):1-12. https://doi.org/10.4103/2231-0762.151956 
[11] Fouad AF. Endodontic Microbiology. Hoboken: John Wiley and Sons, Inc; 2017.

[12] Ramachandran G. Gram-positive and gram-negative bacterial toxins in sepsis: a brief review. Virulence 2014; 5(1):213-8. https://doi.org/10.4161/viru.27024

[13] Gomes BPFA, Martinho FC, Vianna ME. Comparison of $2.5 \%$ sodium hypochlorite and $2 \%$ chlorhexidine gel on oral bacterial lipopolysaccharide reduction from primarily infected root canals. J Endod 2009; 35(10):1350-3. https://doi.org/10.1016/j.joen.2009.06.011

[14] Cardoso FGR, Ferreira NS, Martinho FC, Nascimento GG, Manhães Jr LRC, Rocco MA, et al. Correlation between volume of apical periodontitis determined by cone-beam computed tomography analysis and endotoxin levels found in primary root canal infection. J Endod 2015; 41(7):1015-9. https://doi.org/10.1016/j.joen.2015.02.005

[15] Neelakantan P, Ahmed HMA, Chang JWW, Nabhan MS, Wei X, Cheung GSP, et al. Effect of instrumentation systems on endotoxin reduction from root canal systems: a systematic review of clinical studies and meta-analysis. Aust Endod J 2019; 45(3):407-13. https://doi.org/10.1111/aej.12333

[16] Panic N, Leoncini E, De Belvis G, Ricciardi W, Boccia S. Evaluation of the endorsement of the preferred reporting items for systematic reviews and meta-analysis (PRISMA) statement on the quality of published systematic review and meta-analyses. PloS One 2013; 8(12):e83138. https://doi.org/10.1371/journal.pone.0083138

[17] Higgins JPT, Thomas J, Chandler J, Cumpston M, Li T, Page MJ, Welch VA (editors). Cochrane Handbook for Systematic Reviews of Interventions. 2nd Edition. Chichester (UK): John Wiley \& Sons, 2019.

[18] Martinho FC, Freitas LF, Nascimento GG, Fernandes AM, Leite FRM, Gomes APM, et al. Endodontic retreatment: clinical comparison of reciprocating systems versus rotary system in disinfecting root canals. Clin Oral Investig 2015; 19(6):1411-7. https://doi.org/10.1007/s00784-014-1360-9

[19] Neves MAS, Provenzano JC, Rôças IN, Siqueira Jr JF. Clinical antibacterial effectiveness of root canal preparation with reciprocating single-instrument or continuously rotating multi-instrument systems. J Endod 2016; 42(1):25-9. https://doi.org/10.1016/j.joen.2015.09.019

[20] Cavalli D, Toia CC, Orozco EIF, Khoury RD, Cardoso FGR, Alves MC, et al. Effectiveness in the removal of endotoxins and microbiological profile in primary endodontic infections using 3 different instrumentation systems: a randomized clinical study. J Endod 2017; 43(8):1237-45. https://doi.org/10.1016/j.joen.2017.03.032

[21] Machado MEL, Nabeshima CK, Leonardo MFP, Reis FAS, Britto MLB, Cai S. Influence of reciprocating single-file and rotary instrumentation on bacterial reduction on infected root canals. Int Endod J 2013; 46(11):1083-7. https://doi.org/10.1111/iej.12108

[22] Limoeiro AGS, Santos AHB, De Martin AS, Kato AS, Fontana CE, Gavini G, et al. Micro-computed tomographic evaluation of 2 nickel-titanium instrument systems in shaping root canals. J Endod 2016; 42(3):496-9. https://doi.org/10.1016/j.joen.2015.12.007

[23] Figdor D, Brundin M. Contamination controls for analysis of root canal samples by molecular methods: an overlooked and unsolved problem. J Endod 2016; 42(7):1003-8. https://doi.org/10.1016/j.joen.2016.04.015

[24] Martinho FC, Gomes APM, Fernandes AMM, Ferreira NS, Endo MS, Freitas LF, et al. Clinical comparison of the effectiveness of single-file reciprocating systems and rotary systems for removal of endotoxins and cultivable bacteria from primarily infected root canals. J Endod 2014; 4O(5):625-9. https://doi.org/10.1016/j.joen.2013.12.006

[25] Alves FRF, Rôças IN, Almeida BM, Neves MAS, Zoffoli J, Siqueira Jr JF. Quantitative molecular and culture analyses of bacterial elimination in oval-shaped root canals by a single-file instrumentation technique. Int Endod J 2012; 45(9):871-7. https://doi.org/10.1111/j.1365-2591.2012.02045.x

[26] Ferrer-Luque CM, Bejarano I, Ruiz-Linares M, Baca P. Reduction in Enteroccocus faecalis counts - a comparison between rotary and reciprocating systems. Int Endod J 2014; 47(4):380-6. https://doi.org/10.1111/iej.12158

[27] Rôças IN, Lima KC, Siqueira Jr JF. Reduction in bacterial counts in infected root canals after rotary or hand nickeltitanium instrumentation - a clinical study. Int Endod J 2013; 46(7):681-7. https://doi.org/10.1111/iej.12045

[28] Fabricius L, Dahlén G, Sundqvist G, Happonen RP, Möller ÅJR. Influence of residual bacteria on periapical tissue healing after chemomechanical treatment and root filling of experimentally infected monkey teeth. Eur J Oral Sci 2006; 114(4):278-85. https://doi.org/10.1111/j.1600-0722.2006.00380.x

[29] Vera J, Siqueira Jr JF, Ricucci D, Loghin S, Fernández N, Flores B, et al. One-versus two-visit endodontic treatment of teeth with apical periodontitis: a histobacteriologic study. J Endod 2012; 38(8):1040-52. https://doi.org/10.1016/j.joen.2012.04.010

[30] Tomson PL, Simon SR. Contemporary cleaning and shaping of the root canal system. Prim Dent J 2016; 5(2):46-53.

[31] Yang G, Yuan G, Yun X, Zhou X, Liu B, Wu H. Effects of two nickel-titanium instrument systems, Mtwo versus ProTaper universal, on root canal geometry assessed by micro-computed tomography. J Endod 2011; 37(10):1412-6. https://doi.org/10.1016/j.joen.2011.06.024

[32] Machado MEL, Sapia LAB, Cai S, Martins GHR, Nabeshima CK. Comparison of two rotary systems in root canal preparation regarding disinfection. J Endod 2010; 36(7):1238-40. https://doi.org/10.1016/j.joen.2010.03.012

[33] Siddique R, Nivedhitha MS. Effectiveness of rotary and reciprocating systems on microbial reduction: A systematic review. J Conserv Dent 2019; 22(2):114-22. https://doi.org/10.4103/jcd.jcd_523_18 